\title{
ALTERNATION OF COWPEA GENOTYPES AFFECTS THE BIOLOGY OF Callosobruchus maculatus (FABR.) (COLEOPTERA: BRUCHIDAE)
}

\author{
Marcileyne Pessôa Leite de Lima; José Vargas de Oliveira*; Reginaldo Barros; Jorge Braz \\ Torres
}

UFRPE - Depto. de Agronomia, Av. Dom Manoel de Medeiros, s/n. Dois Irmãos - 52171-900 - Recife, PE - Brasil. *Corresponding author 〈vargasoliveira@uol.com.br>

\begin{abstract}
Callosobruchus maculatus (Fabr.) is an important pest in stored cowpea, Vigna unguiculata (L.) Walp., with ample distribution in tropical and subtropical regions. The effect of alternation of cowpea genotypes, susceptible (S) and resistant (R), on the biology of (C. maculatus) was studied after four generations. A no-choice test was carried out in a completely randomized design, factorial scheme, with five treatments, four host combinations (RR, RS, SR and SS) and five replications. Each replication consisted of 30 grains of each genotype infested by two insect couples. The number of eggs per female was not different within or between combinations, evidencing that the genotypes and their alternation did not affect $C$. maculatus fecundity. Egg viability, however, varied between genotypes and between combinations. In combination RR, the longest duration of the immature stage was verified for genotype IT89KD-245; in addition, all genotypes presented the smallest survival for the same stage, resulting in a higher mortality of the pest. The resistance index categorized combination RR as moderately resistant for genotypes IT89KD-245, BR14-Mulato and BR17Gurguéia, and as susceptible (S) only for IT89KD-260, demonstrating that these combinations were not very adequate for the development of $C$. maculatus, a fact that was confirmed by the better performance of the pest on the genotype from combination SS, and because of a reduction in its performance when it returned to resistant genotypes.
\end{abstract}

Key words: insecta, plant resistance, antibiosis, stored cowpea pest

\section{ALTERNÂNCIA DE GENÓTIPOS DE CAUPI AFETA A BIOLOGIA DE Callosobruchus maculatus (FABR.) (COLEOPTERA: BRUCHIDAE)}

\begin{abstract}
RESUMO: Callosobruchus maculatus (Fabr.) é uma importante praga do caupi, Vigna unguiculata (L.) Walp. armazenado, com ampla distribuição em regiões tropical e subtropical. Avaliou-se o efeito da alternância de genótipos de caupi, suscetível (S) e resistente (R), após quatro gerações, na biologia de (C. maculatus). Utilizou-se o teste sem chance de escolha, em delineamento experimental inteiramente casualizado, em esquema fatorial, com cinco tratamentos, quatro combinações de hospedeiros (RR, RS, SR e SS) e cinco repetições. Cada repetição foi constituída por 30 grãos de cada genótipo infestado com dois casais desta praga. O número de ovos por fêmea não diferiu dentro nem entre as combinações, evidenciando que os genótipos e sua alternância não afetaram a fecundidade de $C$. maculatus. Já a viabilidade de ovos variou entre os genótipos e entre as combinações. Na combinação RR, constatou-se a maior duração da fase imatura no genótipo IT89KD-245 e a menor sobrevivência desta fase em todos os genótipos, resultando em uma maior mortalidade da praga. $\mathrm{O}$ índice de resistência classificou a combinação RR como moderadamente resistente nos genótipos IT89KD245, BR14-Mulato e BR17-Gurguéia, e como S apenas em IT89KD-260, demonstrando que estas combinações foram menos adequadas ao desenvolvimento de $C$. maculatus, fato verificado pelo melhor desempenho da praga sobre o genótipo na combinação SS e pela redução de seu desempenho quando retornava para os genótipos resistentes.

Palavras-chave: insecta, planta resistente, antibiose, praga do caupi armazenado
\end{abstract}

\section{INTRODUCTION}

The bruchid Callosobruchus maculatus (Fabr.) is an important pest of stored cowpea, Vigna unguiculata (L.) Walp., with ample distribution in tropical and subtropical regions, where this crop represents one of the main sources of protein in human diet. The insect infests the cowpea before harvest and causes quantitative and qualitative losses to seeds in storage facilities (Singh, 1978; Mbata, 1993; Shade et al., 1996).

Because it is easy to utilize, costs little and is compatible with other control tactics, genotype resistance emerges as a potential option to minimize losses caused by $C$. maculatus during storage, especially because cowpea is a crop of low economic return. However, the development of resistant cultivars is still very limited, since 
few high-resistance sources have been identified (Singh et al., 1985; Dongre et al., 1996). Another problem that can jeopardize its utilization when it occurs frequently and in high proportions, is the genetic variability of $C$. maculatus. This variability is capable of changing the plant-insect relationship as a result of selection pressure imposed by genotypes after several generations, resulting in biotype development (Messina \& Renwick, 1985; Dick \& Credland, 1986a, 1986b; Mbata, 1993; Shade et al., 1996).

Knowledge on $C$. maculatus biotypes has not been adequately utilized in evaluating resistant genotypes of cowpea. Cowpea genotypes that exhibit significant resistance levels of a single Nigerian population were produced at the International Institute of Tropical Agriculture (IITA) (Ofuya \& Credland, 1995). These authors, working with three populations of the bruchid from Cameroon, Brazil and Burkina Faso, observed variability in bruchid response to cowpea genotypes, demonstrating that resistance assays must be performed using different populations.

The existence of biotypes capable of developing normally on resistant plants has frequently hampered pest management programs. An efficient strategy to avoid the development of these populations is to periodically control alternation of cultivars with different degrees of resistance or distinct background, or their association in the same area (Beck \& Schoonhoven, 1984). Therefore, the objective of this paper was to evaluate the effect of alternating cowpea genotypes (susceptible and resistant) on the biology of a population of $C$. maculatus.

\section{MATERIAL AND METHODS}

The experiment was carried out in Recife, PE, Brazil, under a temperature regime of $27.5 \pm 0.9^{\circ} \mathrm{C}$ and $64.6 \pm 2 \%$ relative humidity, recorded daily by a thermohygrograph, and $12 \mathrm{~h}$ of photophase. To obtain uniform materials, five cowpea genotypes from the Germplasm Collection of Embrapa/Meio Norte (CNPMN), Teresina, PI, Brazil, were multiplied in Vitória de Santo Antão, PE, Brazil ( $8^{\circ} 07^{\prime} 05^{\prime \prime} \mathrm{S}, 35^{\circ} 17^{\prime} 29^{\prime}$ ' W). After harvesting and processing, grains were placed in plastic bags and kept in a freezer at $-5^{\circ} \mathrm{C}$ to eliminate $C$. maculatus infestations coming from the field. Before installing the experiments, grains were removed from the freezer and placed in plastic containers $(6 \mathrm{~cm}$ high by $6 \mathrm{~cm}$ in diameter) covered with voile and maintained in the laboratory for six days to achieve hygroscopic equilibrium.

Thirty intact grains of resistant genotypes BR17Gurguéia, BR14-Mulato, IT89KD-260, IT89KD-245 and CNC 0434, and of the susceptible genotype CNCx 40912F (Lima et al., 2001) were placed in similar plastic containers, with lids containing small holes and covered with voile to promote aeration. Grains were infested with two 0-24-h old C. maculatus couples, from the fourth day of emergence of the fourth generation of insects maintained in the laboratory on each of the genotypes. The insects remained confined in the plastic containers with cowpea grains during six days for oviposition (Santos, 1976). Daily observation of the number of emerged insects was performed and their removal started 25 days after infestation (DAI) and continued for 23 days when no more insects emerged. Following the same procedure, two sixthgeneration couples from each treatment were removed on the fourth day of emergence and used for infestation of alternative genotypes (susceptible and resistant). In addition to the six generations of the pest successively reared on the same resistant genotype (RR), the other treatments were possible for insects reared in each resistant cowpea genotype: the fifth and sixth generations on the susceptible genotype (SS); the fifth generation on the susceptible and the sixth generation on the same genotype used for rearing until the fourth generation (SR); the fifth generation on the same genotype used for rearing until the fourth generation and the sixth generation on the susceptible genotype (RS) (Figure 1).

The response of $C$. maculatus to the genotypes was evaluated for the sixth generation based on the number of eggs per female (fecundity), egg viability (fertility), duration of the immature stage (period from egg to adult), survival of the immature stage (percentage of emerged insects), and resistance index. Egg viability was calculated based on the number of viable eggs relative to the total number of egg. Viable eggs were recognized by their morphological aspect, since they became opaque as a function of the residues discharged by the larvae during their penetration into grains. To calculate duration of the immature stage, the following relation was used: [S(daily number of emerged insects $\mathrm{x}$ number of DAI)/ total emerged insects]. The survival of the immature stage

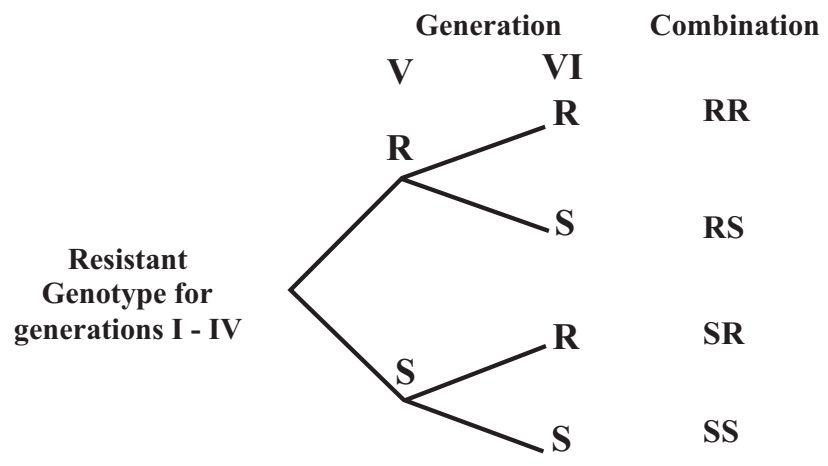

Figure 1 - Alternation of cowpea genotypes after the fourth generation of a population of $C$. maculatus, and resulting combinations. $\mathrm{R}=$ resistant genotype on which the insects were reared for the first 4 generations (BR17Gurguéia, BR14-Mulato, IT89KD-260, IT89KD-245 and CNC 0434); $\mathrm{S}=$ susceptible genotype $\mathrm{CNCx} 409$ $12 \mathrm{~F}$. 
was obtained based on the total emerged adults relative to the number of viable eggs. The formula proposed by Kornegay et al. (1993) was used to calculate the resistance index: $\ln \{[$ (number of emerged insects/number of viable eggs) +1 /duration of immature stage] $\mathrm{x} 100\}$.

A completely randomized design in a factorial scheme was utilized, with five treatments, four host combinations (RR, RS, SR and SS) and five replicates. The data pertaining to the number of eggs per female, egg viability, duration and survival of the immature stage were submitted to the Lilliefors test for normality of variance and to analysis of variance (ANOVA), and the Scott-Knott test $(P=0.05)$ was used to separate means (Scott \& Knott, 1974). Genotypes, when evaluated by the resistance index (Kornegay et al., 1993), were separated based on the confidence interval 95\% (CI) $(P=0.05)$ (unpublished data) and classified in three degrees of resistance: $\mathrm{MR}=$ moderately resistant $(\mathrm{Mc} / \mathrm{l}<\mathrm{Mc} / \mathrm{lt}-\mathrm{CI}), \mathrm{S}=$ susceptible $(\mathrm{Mc} / \mathrm{lt}-\mathrm{CI} £ \mathrm{Mc} / \mathrm{l} £ \mathrm{Mc} / \mathrm{lt}+\mathrm{CI})$ and $\mathrm{HS}=$ highly susceptible $(\mathrm{Mc} / \mathrm{l}>\mathrm{Mc} / \mathrm{lt}+\mathrm{CI})$ where $\mathrm{Mc} / \mathrm{l}$ is the mean of five replicates for the genotype and $\mathrm{Mc} / \mathrm{lt}$ is the mean for all the tested genotypes.

\section{RESULTS AND DISCUSSION}

The number of eggs per female $C$. maculatus ranged from 66.8 on BR17-Gurguéia to 80.2 on IT89KD-
260. No differences within or between host combinations were observed, evidencing that the genotypes and their alternation did not affect pest fecundity (Table 1). Singh (1978) and IITA (1981) verified the same behavior for the cultivar TVu 2027, which is highly resistant due to antibiosis, since it oviposited as much as the susceptible.

Egg viability in $C$. maculatus presented variation between genotypes and between combinations, characterizing an effect on fertility, i.e., on the number of eggs that originated larvae (Table 2). The smallest observed viability was $75.8 \%$ in RR for insects maintained for six generations on BR14-Mulato, just differing from BR17Gurguéia and CNC 0434 genotypes. This negative genotype effect could be chemical in nature or attributed to morphological characteristics of the grain that prevented penetration of the bruchid. Among the genotype combinations, BR14-Mulato had a viability of $87.3 \%$ for the RS combination, $91.9 \%$ for SS combination, $75.8 \%$ for $\mathrm{RR}$, and $80.3 \%$ for MR combinations. This demonstrates that insects maintained on resistant genotypes and, soon after, on susceptible genotypes, have their egg viability increased. On the other hand, BR17-Gurguéia and CNC 0434 genotypes under the different combinations had little effect on pest egg viability.

Although significant, the variation in duration of the immature stage of $C$. maculatus (Table 3) was not very large, corresponding to a maximum difference of only 1.1

Table 1 - Number of eggs per female C. maculatus (Mean \pm CI) reared on cowpea genotypes in different combinations for two generations. Temperature: $27.5 \pm 0.9^{\circ} \mathrm{C}$; RH: $64.6 \pm 2 \%$; Photophase: $12 \mathrm{~h}$.

\begin{tabular}{lcccc}
\hline & \multicolumn{3}{c}{ Combinations $^{1.2}$} \\
\cline { 2 - 5 } Genotypes & RR & RS & SR & SS \\
\hline BR17-Gurguéia & $66.8 \pm 8.54$ & $74.8 \pm 5.85$ & $71.9 \pm 5.24$ & $78.9 \pm 5.39$ \\
BR14-Mulato & $76.7 \pm 2.69$ & $72.5 \pm 3.32$ & $73.6 \pm 3.26$ & $72.1 \pm 4.93$ \\
IT89KD-260 & $80.2 \pm 5.68$ & $77.9 \pm 8.57$ & $74.5 \pm 6.40$ & $79.2 \pm 9.86$ \\
IT89KD-245 & $69.8 \pm 10.29$ & $76.6 \pm 10.44$ & $68.1 \pm 6.93$ & $75.8 \pm 3.85$ \\
CNC 0434 & $77.3 \pm 6.43$ & $79.3 \pm 9.63$ & $72.8 \pm 10.92$ & $79.2 \pm 5.37$ \\
\hline
\end{tabular}

${ }^{1}$ No differences were observed between means using Scott-Knott test $(P=0.05)$.

${ }^{2} \mathrm{RR}=$ Resistant and Resistant; RS = Resistant and Susceptible; SR = Susceptible and Resistant; SS = Susceptible and Susceptible, on the fifth and sixth generations, respectively. The susceptible standard was CNCx 409-12F.

Table 2 - Percent viability of $C$. maculatus eggs (Mean $\pm \mathrm{CI}$ ) reared on cowpea genotypes for different combinations and two generations. Temperature: $27.5 \pm 0.9{ }^{\circ} \mathrm{C}$; RH: $64.6 \pm 2 \%$; Photophase: $12 \mathrm{~h}$.

\begin{tabular}{|c|c|c|c|c|}
\hline \multirow[b]{2}{*}{ Genotypes } & \multicolumn{4}{|c|}{ Combinations ${ }^{1.2}$} \\
\hline & $\mathrm{RR}$ & $\mathrm{RS}$ & SR & SS \\
\hline BR17-Gurguéia & $94.2 \pm 1.83 \mathrm{aA}$ & $91.2 \pm 2.58 \mathrm{aA}$ & $92.0 \pm 4.82 \mathrm{aA}$ & $82.1 \pm 10.58 \mathrm{aB}$ \\
\hline BR14-Mulato & $75.8 \pm 7.24 \mathrm{bB}$ & $87.3 \pm 4.93 \mathrm{bA}$ & $80.3 \pm 0.82 \mathrm{bB}$ & $91.9 \pm 5.62 \mathrm{aA}$ \\
\hline IT89KD-260 & $84.7 \pm 5.12 \mathrm{bA}$ & $92.1 \pm 4.34 \mathrm{aA}$ & $79.3 \pm 8.81 \mathrm{bA}$ & $89.4 \pm 6.50 \mathrm{aA}$ \\
\hline IT89KD-245 & $84.4 \pm 9.34 \mathrm{bA}$ & $95.1 \pm 2.12 \mathrm{aA}$ & $90.1 \pm 4.94 \mathrm{aA}$ & $94.7 \pm 2.21 \mathrm{aA}$ \\
\hline CNC 0434 & $92.2 \pm 2.09 \mathrm{aB}$ & $95.2 \pm 1.23 \mathrm{aA}$ & $94.0 \pm 2.22 \mathrm{aB}$ & $97.1 \pm 0.66 \mathrm{aA}$ \\
\hline
\end{tabular}

${ }^{1}$ Means followed by the same lower case letter in the column, and upper case letter in the row, are not different by Scott-Knott test $(P=0.05)$.

${ }^{2} \mathrm{RR}=$ Resistant and Resistant; RS = Resistant and Susceptible; SR = Susceptible and Resistant; SS = Susceptible and Susceptible, on the fifth and sixth generations, respectively. The susceptible standard was CNCx 409-12F. 
day for SR. This observation agrees with results obtained by Pessoa et al. (1993), who observed a difference of one day between cowpea cultivars. The longest duration for this stage was obtained for IT89KD-245 for the combinations RR and SR, demonstrating that these combinations are not very adequate for bruchid development as compared to the other genotype combinations. However, the differences are small and may not be biologically meaningful.

All the genotypes presented less percentage of survival at the immature stage ( $\%$ of emerged adults) in the combination RR, the causal factors for this performance not having been established (Table 4). The largest number of emerged insects was verified when host alternation occurred, especially when the last generation was maintained on susceptible hosts, confirming that the resistant genotypes were not favorable to the progeny of the pest.

According to the resistance index (Kornegay et al., 1993) the combination RR was classified as moderately resistant (MR) for genotypes IT89KD-245, BR14Mulato and BR17-Gurguéia, and as susceptible (S) only for IT89KD-260 (Table 5), that is, these combinations were not very adequate for the development of $C$. maculatus. When the susceptible host was used for the $6^{\text {th }}$ generation, it was observed better performance of the pest, confirmed by the change in the classification in the resistance index (Table 5). Genotype IT89KD-245 changed to highly susceptible (HS) for the RS combination. Lima et al. (2002) have observed that the IT89KD245 genotype also behaved as moderately resistant (MR) for six C. maculatus generations, when the resistance index was used as evaluation parameter.

The frequent utilization of genotypes with high levels of resistance could promote the development of biotypes resulting from selection pressure, especially when the insect shows high genetic variability, as it is the case with $C$. maculatus. Therefore, the alternation of hosts with different degrees of resistance is very important as a strategy to avoid the occurrence of resistant populations. Schoonhoven \& Cardona (1982), working for five generations with Zabrotes subfasciatus (Boh.) on resistant and susceptible genotypes of common beans, Phaseolus vulgaris L., did not find expressive variations in insect resistance to the host. This resistance would disappear when the insects were again reared on a susceptible cultivar, which could be explained by their adaptability. If the adaptive cost of resistance to certain cultivars is high, in the absence of selection pressure the susceptibility condition could occur more rapidly. This would indicate that

Table 3 - Duration in days of the immature stage (Mean \pm CI) of C. maculatus reared on cowpea genotypes for different combinations and two generations. Temperature: $27.5 \pm 0.9{ }^{\circ} \mathrm{C}$; RH: $64.6 \pm 2 \%$; Photophase: $12 \mathrm{~h}$.

\begin{tabular}{lcccc}
\hline & \multicolumn{4}{c}{ Combinations $^{1.2}$} \\
\cline { 2 - 5 } Genotypes & RR & RS & SR & SS \\
\hline BR17-Gurguéia & $28.2 \pm 0.16 \mathrm{cB}$ & $28.3 \pm 0.46 \mathrm{bB}$ & $28.9 \pm 0.42 \mathrm{bA}$ & $28.8 \pm 0.40 \mathrm{aA}$ \\
BR14-Mulato & $28.7 \pm 0.13 \mathrm{bB}$ & $28.4 \pm 0.39 \mathrm{bB}$ & $29.7 \pm 0.52 \mathrm{aA}$ & $28.3 \pm 0.05 \mathrm{aB}$ \\
IT89KD-260 & $28.8 \pm 0.34 \mathrm{bA}$ & $29.1 \pm 0.27 \mathrm{aA}$ & $28.7 \pm 0.24 \mathrm{bA}$ & $28.8 \pm 0.30 \mathrm{aA}$ \\
IT89KD-245 & $29.2 \pm 0.39 \mathrm{aA}$ & $28.4 \pm 0.14 \mathrm{bB}$ & $29.7 \pm 0.29 \mathrm{aA}$ & $28.5 \pm 0.23 \mathrm{aB}$ \\
CNC 0434 & $28.7 \pm 0.25 \mathrm{bA}$ & $28.6 \pm 0.27 \mathrm{bA}$ & $28.6 \pm 0.24 \mathrm{bA}$ & $28.8 \pm 0.31 \mathrm{aA}$ \\
\hline
\end{tabular}

${ }^{1}$ Means followed by the same lower case letter in the column, and upper case letter in the row, are not different by Scott-Knott test $(P=0.05)$.

${ }^{2} \mathrm{RR}=$ Resistant and Resistant; RS = Resistant and Susceptible; SR = Susceptible and Resistant; SS = Susceptible and Susceptible, on the fifth and sixth generations, respectively. The susceptible standard was CNCx 409-12F.

Table 4 - Percent survival at the immature stage (Mean \pm CI) of $C$. maculatus reared on cowpea genotypes for different combinations for two generations. Temperature: $27.5 \pm 0.9^{\circ} \mathrm{C}$; RH: $64.6 \pm 2 \%$; Photophase: $12 \mathrm{~h}$.

\begin{tabular}{lcccc}
\hline & \multicolumn{4}{c}{ Combinations $^{1.2}$} \\
\cline { 2 - 5 } Genotypes & RR & RS & SR & SS \\
\hline BR17-Gurguéia & $76.0 \pm 8.78 \mathrm{aB}$ & $88.6 \pm 3.13 \mathrm{aA}$ & $76.9 \pm 4.31 \mathrm{bB}$ & $84.3 \pm 7.85 \mathrm{aA}$ \\
BR14-Mulato & $63.9 \pm 6.10 \mathrm{aC}$ & $87.3 \pm 3.17 \mathrm{aA}$ & $79.6 \pm 2.79 \mathrm{bB}$ & $85.7 \pm 3.57 \mathrm{aA}$ \\
IT89KD-260 & $61.8 \pm 10.07 \mathrm{aB}$ & $84.1 \pm 5.93 \mathrm{aA}$ & $86.2 \pm 5.35 \mathrm{aA}$ & $85.9 \pm 3.42 \mathrm{aA}$ \\
IT89KD-245 & $63.7 \pm 7.88 \mathrm{aC}$ & $88.7 \pm 3.56 \mathrm{aA}$ & $74.4 \pm 3.91 \mathrm{bB}$ & $86.3 \pm 2.59 \mathrm{aA}$ \\
CNC 0434 & $65.3 \pm 3.53 \mathrm{aA}$ & $84.9 \pm 3.23 \mathrm{aA}$ & $77.0 \pm 8.28 \mathrm{bA}$ & $76.0 \pm 14.88 \mathrm{aA}$ \\
\hline
\end{tabular}

${ }^{1}$ Means followed by the same lower case letter in the column, and upper case letter in the row, are not different by Scott-Knott test $(P=0.05)$.

${ }^{2} \mathrm{RR}=$ Resistant and Resistant RS = Resistant and Susceptible; SR = Susceptible and Resistant; SS = Susceptible and Susceptible, on the fifth and sixth generations, respectively. The susceptible standard was CNCx 409-12F. 
Table 5 - Classification of cowpea genotypes relative to C. maculatus based on their resistance index. Temperature: $27.5 \pm$ $0.9^{\circ} \mathrm{C}$; RH: $64.6 \pm 2 \%$; Photophase: $12 \mathrm{~h}$.

\begin{tabular}{|c|c|c|c|c|c|c|c|c|}
\hline \multirow[b]{2}{*}{ Genotypes } & \multicolumn{2}{|c|}{$\mathrm{RR}$} & \multicolumn{2}{|r|}{$\mathrm{RS}$} & \multicolumn{2}{|c|}{ SR } & \multicolumn{2}{|c|}{ SS } \\
\hline & $\begin{array}{l}\text { Resistance } \\
\text { Index }\end{array}$ & Classification & $\begin{array}{l}\text { Resistance } \\
\text { Index }\end{array}$ & Classification & $\begin{array}{l}\text { Resistance } \\
\text { Index }\end{array}$ & Classification & $\begin{array}{l}\text { Resistance } \\
\text { Index }\end{array}$ & Classification \\
\hline $\begin{array}{l}\text { BR17- } \\
\text { Gurguéia }\end{array}$ & 1.98 & MR & 2.24 & HS & 1.98 & $\mathrm{~S}$ & 2.12 & S \\
\hline $\begin{array}{l}\text { BR14- } \\
\text { Mulato }\end{array}$ & 2.01 & MR & 2.21 & $\mathrm{~S}$ & 1.97 & S & 2.18 & HS \\
\hline $\begin{array}{l}\text { IT89KD- } \\
260\end{array}$ & 2.12 & S & 2.09 & MR & 2.16 & HS & 2.15 & S \\
\hline $\begin{array}{l}\text { IT89KD- } \\
245\end{array}$ & 1.94 & MR & 2.23 & HS & 1.87 & MR & 2.19 & HS \\
\hline $\begin{array}{l}\text { CNC } \\
0434\end{array}$ & 2.11 & S & 2.15 & S & 1.98 & $\mathrm{~S}$ & 1.96 & MR \\
\hline
\end{tabular}

${ }^{1} \mathrm{MR}=$ moderately resistant; $\mathrm{S}=$ susceptible; HS = highly susceptible. Separation was made based on the confidence interval (CI).

${ }^{2} \mathrm{RR}=$ Resistant and Resistant; RS = Resistant and Susceptible; SR = Susceptible and Resistant; SS = Susceptible and Susceptible, on the fifth and sixth generations, respectively. The susceptible standard was CNCx 409-12F.

the insects do not adapt by prolonged rearing on resistant genotypes. When they return from susceptible to resistant genotypes, the original resistance would be immediately reestablished as observed in this study, especially on IT89KD-245 and BR14-Mulato. Even though some genotype effects were observed on the biology of $C$. maculatus, the levels of resistance were not high enough to cause the development of biotypes in the bruchid populations. Further research is needed to evaluate new cowpea genotypes with higher resistance for several $C$. maculatus generations.

\section{REFERENCES}

BECK, S.D.; SCHOONHOVEN, L.M. Conducta de los insectos y resistencia vegetal. In: MAXWELL, F.G.; JENNINGS, P.R. (Ed.) Mejoramiento de plantas resistentes a insectos. México: Editorial Limusa, 1984. p.135-156.

DICK, K.M.; CREDLAND, P.F. Changes in the response of Callosobruchus maculatus (F.) (Coleoptera: Bruchidae) to a resistant variety of cowpea. Journal of Stored Products Research, v.22, p.227-233, 1986a.

DICK, K.M.; CREDLAND, P.F. Variation in the response of Callosobruchus maculatus (F.) to a resistant variety of cowpea. Journal of Stored Products Research, v.22, p.43-48, 1986b.

DONGRE, T.K.; PAWAR, S.E.; THAKARE, R.G.; HARWALKAR, M.R. Identification of resistant sources to cowpea weevil (Callosobruchus maculatus (F.) in Vigna sp. and inheritance of their resistance in black gram (Vigna mungo var. mungo). Journal of Stored Products Research, v.32, p.201-204, 1996.

INTERNATIONAL INSTITUTE OF TROPICAL AGRICULTURE - IITA. Annual Report for 1980. Ibadan, Nigeria: IITA, 1981. p.117-137.

KORNEGAY, J.; CARDONA, C.; POSSO, C.E. Inheritance of resistance to Mexican bean weevil in common bean, determined by bioassay and biochemical tests. Crop Science, v.33, p.589-594, 1993.

LIMA, M.P.L.; OLIVEIRA, J.V.; BARROS, R.; TORRES, J.B. Identificação de genótipos de caupi Vigna unguiculata (L.) Walp. resistentes a Callosobruchus maculatus (Fabr.) (Coleoptera: Bruchidae). Neotropical Entomology, v.30, p.289-295, 2001.
LIMA, M.P.L.; OLIVEIRA, J.V.; BARROS, R.; TORRES, J.B. Estabilidade da resistência de genótipos de caupi a Callosobruchus maculatus (Fabr.) em gerações sucessivas. Scientia Agricola, v.59, p.275-280, 2002.

MBATA, G.N. Evaluation of susceptibility of varieties of cowpea to Callosobruchus maculatus (F.) and Callosobruchus subinnotatus (Pic.) (Coleoptera: Bruchidae). Journal of Stored Products Research, v.29, p.207-213, 1993.

MESSINA, F.J.; RENWICK, J.A.A. Resistance to Callosobruchus maculatus (Coleoptera: Bruchidae) in selected cowpea lines. Environmental Entomology, v.14, p.868-872, 1985.

OFUYA, T.I.; CREDLAND, P.F. Responses of three populations of the seed beetle, Callosobruchus maculatus (F.) (Coleoptera: Bruchidae), to seed resistance in selected varieties of cowpea, Vigna unguiculata (L.) Walp. Journal of Stored Products Research, v.31, p.17-27, 1995.

PESSOA, G.P.; BARROS, R.; OLIVEIRA, J.V. Avaliação da resistência de caupi Vigna unguiculata (L.) Walp. a Callosobruchus maculatus (Fabr.) em confinamento em laboratório. Anais da Sociedade Entomológica do Brasil, v.22, p.259-266, 1993.

SANTOS, J.H.R. Aspectos da resistência de cultivares de Vigna sinensis (L.) Savi ao ataque do Callosobruchus maculatus (Fabr., 1775) (Col., Bruchidae), mantidos no Estado do Ceará - Brasil. Piracicaba: USP/ ESALQ, 1976. 194p. (Tese Doutorado).

SCOTT, A.J.; KNOTT, M.A. A cluster analysis method for grouping means in the analysis of variance. Biometrics, v.30, p.507-512, 1974.

SCHOONHOVEN, A.V.; CARDONA, C. Low levels of resistance to the mexican bean weevil in dry beans. Journal of Economic Entomology, v.75, p.567-569, 1982

SHADE, R.E.; KITCH, L.W.; MENTZER, P.; MURDOCK, L.L. Selection of a cowpea weevil (Coleoptera: Bruchidae) biotype virulent to cowpea weevil resistant Landrace TVu 2027. Journal of Economic Entomology, v. 89, p.1325-1331, 1996.

SINGH, S.R. Resistance to pest of cowpeas in Nigeria. In: SINGH, S.R.; VAN EMDEN, H.F.; TAYLOR, T.A. (Ed.) Pests of grain legumes: ecology and control. London: Academic Press, 1978. p.267-269.

SINGH, B.B.; SINGH, S.R.; ADJADI, O. Bruchid resistance in cowpea. Crop Science, v.25, p.736-739, 1985.

Received October 22, 2002

Accepted October 23, 2003 